\title{
Removing of Hexavalent Chromium from Aqueous Solutions Using Dried Yogurt, and Studying Isotherm, Kinetic and Thermodynamic Parameters
}

\author{
Muntadhar S. Sultan* \\ Layth H. Abdul Ghani
}

\author{
Mahdi F. Radi \\ Asmaa A. Maryoosh
}

Ala'a A. Jasim

Jaleel S. Tahir

Dhifaf A. Abdul abass

\author{
Received 24/6/2018, Accepted 4/2/2019, Published 1/9/2019
}

This work is licensed under a Creative Commons Attribution 4.0 International License.

\begin{abstract}
:
In this study, Yogurt was dried and milled, then shaked with distilled water to remove the soluble materials, then again dried and milled. Batch experiments were carried out to remove hexavalent chromium from aqueous solutions. Different parameters were optimized such as amount of adsorbent, treatment time, $\mathrm{pH}$ and concentration of adsorbate. The concentrations of Cr6+ in solutions are determined by UV-Visible spectrophotometer. Maximum percentage removal of $\mathrm{Cr} 6+$ was $82 \%$ at $\mathrm{pH} 2$. Two equilibrium adsorption isotherms mechanisms are tested Langmuir and Freundlich, the results showed that the isotherm obeyed to Freundlich isotherm. Kinetic models were applied to the adsorption of Cr6+ ions on the adsorbents, pseudofirst-order, the pseudo second-order respectively. Results showed that pseudo second-order kinetic model was applicable to the experimental data well. The thermodynamic parameters such as $\Delta \mathrm{G}^{\circ}, \Delta \mathrm{H}^{\mathrm{o}}$ and $\Delta \mathrm{S}^{\mathrm{o}}$ were calculated. $\Delta \mathrm{H}^{\circ}, \Delta \mathrm{S}^{\circ}$ and $\Delta \mathrm{G}^{\circ}$ for this study were negative indicating that the process is exothermic, while negative values of $\Delta \mathrm{G}^{\mathrm{o}}$ indicate spontaneous process.
\end{abstract}

Key words: Adsorption, Adsorption isotherms, Adsorption kinetics, Hexavalent chromium, Yogurt.

\section{Introduction:}

Metals pollution is one of the modern challenges due to the wide using metals in the industries which caused serious increase of releasing the metals into the environment. There are at least twenty metals classified as toxic substances. Half of these toxic metals are spread in the environment in quantities that pose a danger to human health by causing cancer diseases (1).

There are many sources for metal pollution in the environment, for example chemical and refractory processing, tanning, and mining electroplating. Many metals such as chromium, cadmium, zinc, lead, mercury, and copper are used in various industries $(2,3)$. These industries release solid or liquid wastes polluted by metals into the environment, which leads to increasing levels of environmental pollution. There are two basic valences of chromium tri and hexa valence chromium $\left(\mathrm{Cr}^{3+}\right.$ and $\left.\mathrm{Cr}^{6+}\right)$, The World Health Organization (WHO) recommends a maximum appropriate concentration of $\mathrm{Cr}^{6+}$ as $0.02 \mathrm{mg} / \mathrm{L}$ in wastewater which is discharging outside (4).

Department of Chemistry, College of Science, AlMustansiriyah University.

"Corresponding author:

muntadhar_sultan@uomustansiriyah.edu.iq
It has shown that the hexavalent chromium compounds cause genetic mutations by penetrating cell membranes due to differences in physiochemical properties (5).

Adsorption process can be used for treatment and removal of contaminants as an effective method to reuse contaminated water again. Adsorption technique to remove the toxic metal ions from polluted water is a preferable approaches due to low cost compared with other methods such as chemical precipitation, ion exchange, membrane processes, and liquid extraction (6). One of other advantage is the availability of natural surfaces sources that can be used as adsorbent surfaces, such as clays, agricultural, and organic wastes (7).

This research aims to evaluate the drying yogurt as adsorption surface and optimize the conditions to remove hexavalnce chromium from aqueous solutions, and also study the thermodynamic of adsorption process.

\section{Material and Methods:}

Dry yogurt samples were collected from local market in Baghdad (natural yogurt produced in rural homes without any industrial additives). Sodium hydroxide $(\mathrm{NaOH})$ and Hydrochloric acid $(\mathrm{HCl})$ were purchased from sigma Aldrich and used as 
received. Potassium dichromate $\left(\mathrm{K}_{2} \mathrm{Cr}_{2} \mathrm{O}_{7}\right)$ of analar grade purchased from $(\mathrm{BDH})$.

UV-Visible spectrometer, CARY 100 con Australian made, water bath shaker type lab companion BS-11, digital scale KERN-ABBS and pH meter type trans BP 300 were used in this work.

\section{Experimental}

The yogurt was dried over night at $80^{\circ} \mathrm{C}$, then rinsed with distilled water for 8 hours and dried in an air oven at $80^{\circ} \mathrm{C}$ for overnight. The resulted dried yogurt was passed through $150 \mu \mathrm{m}$ sieve after being milled with agate mortar. Dry yogurt is ready to use as adsorption surface. $1000 \mathrm{mg} / \mathrm{L}$ stock solution of chromium ion $\mathrm{Cr}^{6+}$ was prepared by dissolving $0.2827 \mathrm{~g}$ in $100 \mathrm{~mL}$ distilled water, wavelength of maximum absorption peak $\left(\lambda_{\max }\right)$ was detected at wave length $372 \mathrm{~nm}$ and stabilized for all subsequent measurements, calibration curve was built using UV-Vis absorbance measures for series of concentrations prepared by multi dilution of stock solution. To study different parameters, adsorption experiments were carried out using 50 $\mathrm{mL}$ of series of concentrations. Solutions were prepared by dilution of stock solution for different experiments then using calibration curve to calculate the concentrations for definite time intervals. The percentage of removal $\mathrm{Cr}^{6+}(\mathrm{R} \%)$ was calculated by equation 1 .

$$
\mathrm{R} \%=\frac{\left(\mathrm{C}_{\mathrm{i}}-\mathrm{C}_{e}\right)}{\mathrm{C}_{\mathrm{i}}} \times 100 \ldots \ldots
$$

Where, $C_{i}$ and $C_{e}$ represent the metal ions concentrations $\left(\mathrm{Cr}^{6+} \mathrm{mg} / \mathrm{L}\right)$ at initial and final experiment.

To optimize conditions of the best adsorption capacity and the removal of $\mathrm{Cr}^{6+}$ from the solution,

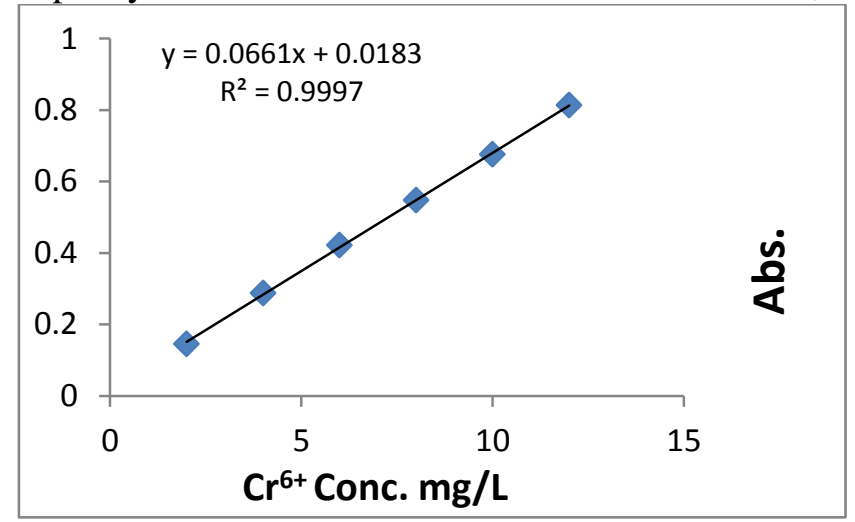

(a) effect of different parameters on adsorption capacity were studied in this work such as time, $\mathrm{pH}$, and initial concentration of yogurt, adsorbent dosage and temperature of adsorption. Adsorption capacity was calculated by equation 2

$$
\mathrm{q}_{\mathrm{e}}=\frac{\left(\mathrm{C}_{\mathrm{i}}-\mathrm{C}_{e}\right) \times \mathrm{V}}{\mathrm{M}}
$$

Also, the adsorption capacity $\left(\mathrm{q}_{\mathrm{t}}\right)$ at time $\mathrm{t}$ was determined using the Equation 3 (8).

$$
\mathrm{q}_{\mathrm{t}}=\frac{\left(\mathrm{C}_{\mathrm{o}}-\mathrm{C}_{t}\right) \times \mathrm{V}}{\mathrm{M}}
$$

Where $C_{o}, C_{e}$ and $C_{t}$ are the metal ions concentrations $(\mathrm{mg} / \mathrm{L})$ at initial, equilibrium and at time $\mathrm{t}, \mathrm{V}$ is the solution volume $(\mathrm{mL})$ of metal ions at initial concentration and $\mathrm{M}$ is adsorbent mass used (g). Kinetic studies of adsorption and adsorption isotherms are carried out in this work to determine reaction order and type of isotherm.

\section{Results and Discussion:}

Removal of metal ions by adsorption depends on several parameters such as contact time, temperature, $\mathrm{pH}$, and adsorbate concentration. Increasing the initial concentration of adsorbate leads to increase the amount of adsorbed qe $(\mathrm{mg} / \mathrm{g})$, and this is due to increase driving force of concentration gradient (9). Also, $\mathrm{pH}$ of the solution has important influence in this process (10).

Calibration curve was built between different concentrations of $\mathrm{Cr}^{6+}(2,4,6,8,10$ and $12 \mathrm{mg} / \mathrm{L})$ and the UV-Vis absorbance, calibration curve showed very good linearity and correlation coefficient $\left(\mathrm{R}^{2}\right)$ of 0.9997 as shown in Fig. 1.

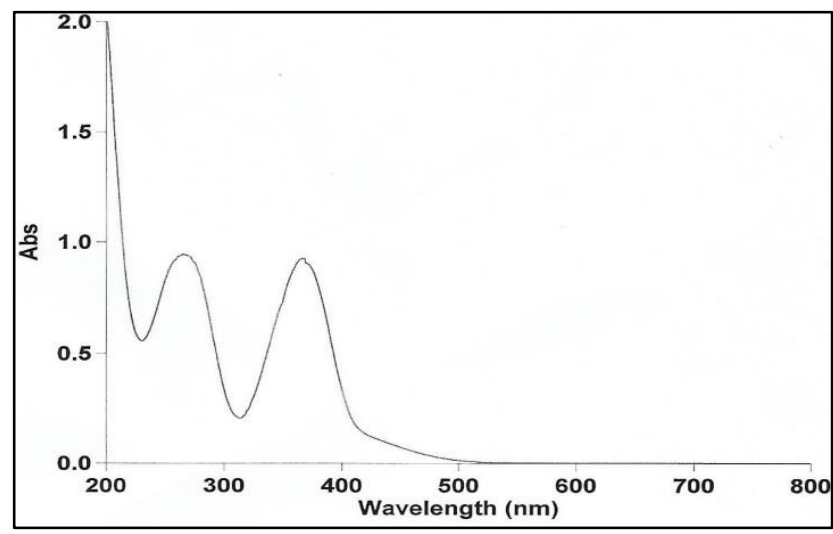

(b)

Figure 1. (a) Calibration curve of $\mathrm{Cr}^{6+}$ Concentration vs Absorbance (b) UV-Vis Absorbance spectrum

This calibration curve was used in all calculations in this work.

\section{Effect of Contact Time}

Ten experiments with different contact time between 10 to 100 minutes and, effect of adsorption contact time on $\mathrm{Cr}^{6+}$ removal are shown in Fig. 2. It can be noticed from the figure that the chromium removal percentage increased with increasing time to about 60 minutes, with the removal rate almost $80 \%$. The maximum $\mathrm{Cr}^{6+}$ removal percentage was $82.12 \%$ at $100 \mathrm{~min}$. 


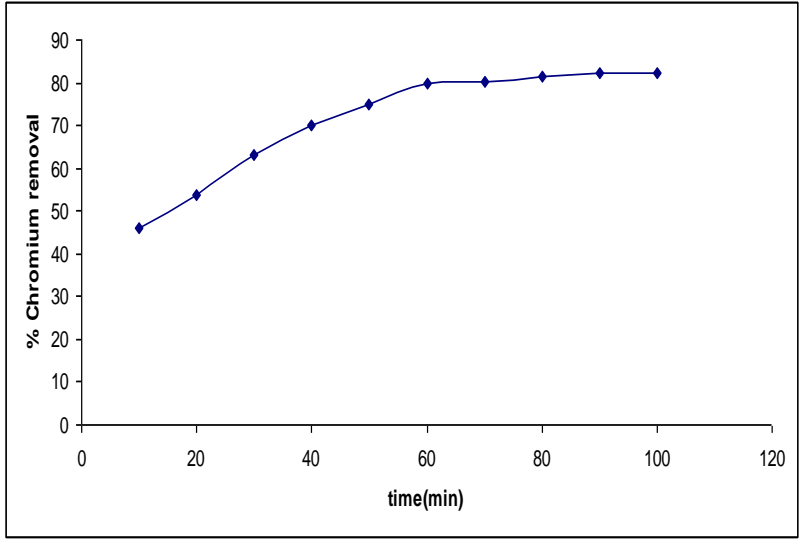

Figure 2. Effect of contact time on adsorption of $\mathrm{Cr}^{6+}$

\section{Effect of pH}

Effect of $\mathrm{pH}$ on the $\mathrm{Cr}^{6+}$ adsorption by waste yogurt was studied over $\mathrm{pH}$ range of 1 to 8 . Different $\mathrm{pH}$ conditions were maintained by sodium acetate buffer. Maximum removal conc. of $\mathrm{Cr}^{6+}$ was observed at $\mathrm{pH} 2$ as shown in Fig. 3. The removal of $\mathrm{Cr}^{6+}$ significantly increased from 1 to $2 \mathrm{pH}$, and then decreased with increasing the $\mathrm{pH}$ of the solution. The chromium removal percentage increased from $31.45 \%$ at $\mathrm{pH} 8.0$ to $82.12 \%$ at $\mathrm{pH}$ 2.0. The maximum adsorption that was observed at pH 2.0 as shown in Fig. 3 may be attributed to the competition between adsorption sites and hydroxyl groups on $\mathrm{Cr}^{6+}$ ions. These results agree with previous studies of chromium adsorption by banana peel and date palm seed (11).

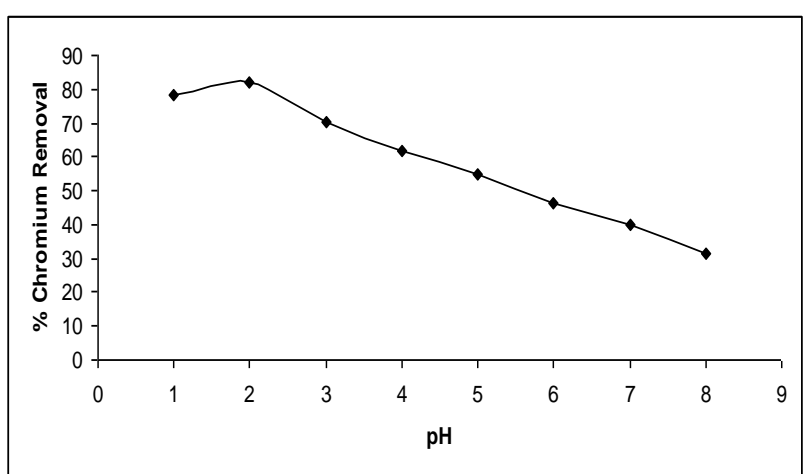

Figure 3. Effect of $\mathrm{pH}$ on adsorption of $\mathrm{Cr}^{6+}$

\section{Effect of Initial Chromium Ion Concentration.}

Series of initial concentrations of $\mathrm{Cr}^{6+}$ between $(10$ to $60 \mathrm{mg} / \mathrm{L})$ were tested to determine the effect of initial concentration on adsorption. The relation between concentration and calculated adsorption capacity (qe) was plotted as shown in Fig. 4. The adsorption capacity qe $(\mathrm{mg} / \mathrm{g})$ increases with increasing the initial concentration of the adsorbate, and this can be attributed to the increase in driving force of the concentration gradient with increase in concentration of chromium (8).

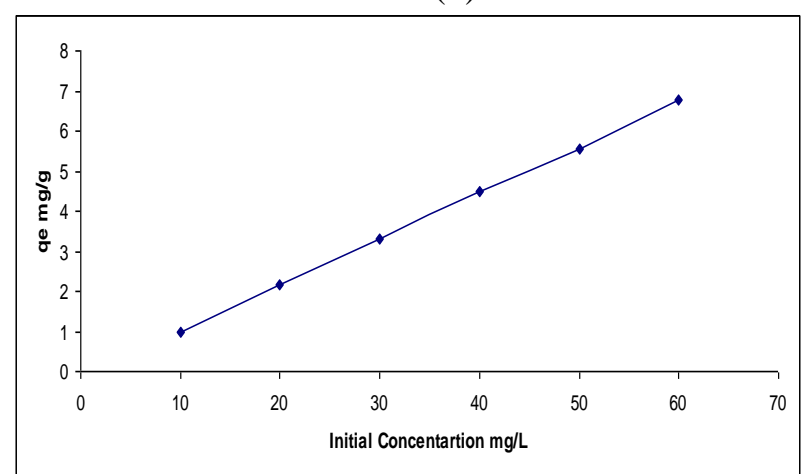

Figure 4. Effect of initial concentration on adsorption of $\mathrm{Cr}^{6+}$

\section{Effect of Adsorbent Dosage}

$50 \mathrm{ml}$ of the $\mathrm{Cr}^{6+}$ solution was exposed for 80 minutes to a dose ranging from 0.05 to $0.5 \mathrm{~g}$ of adsorbent and then the removal percentage for each dose was calculated. Removal percentage was plotted against dosage of adsorbent as shown in Fig. 5; this Figure shows increasing of removal percentage from $0.05 \mathrm{~g}$ with $30 \%$ percentage removal then it reached the maximum value with $84.6 \%$ removal at $0.4 \mathrm{~g} \mathrm{(12)}$.

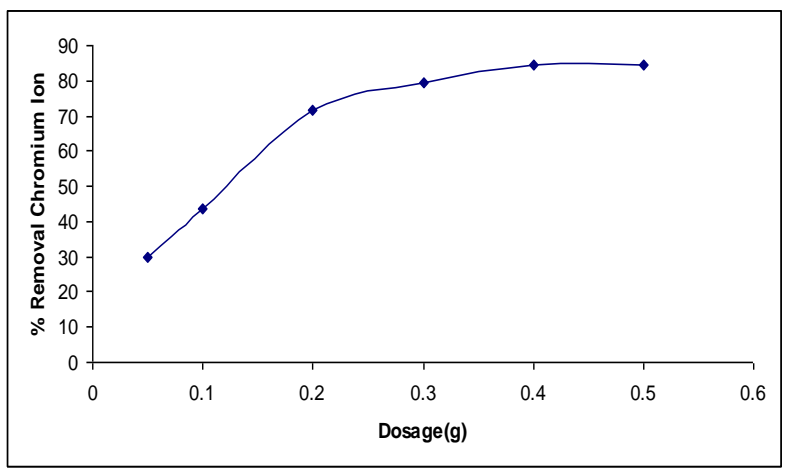

Figure 5. Effect of adsorbent Dosage on removal percentage

\section{Adsorption Isotherms}

There are several equilibrium adsorption isotherms mechanisms to understand the sorption process; two mechanisms have been tested in this work, Langmuir and Freundlich isotherms. Table 1 shows Langmuir and Freundlich constants for this study. 
Table 1. Values of the Langmuir and Freundlich constants for the adsorption of $\mathrm{Cr}^{6+}$ onto drying

\begin{tabular}{ccccc}
\hline Isotherm model & Isotherm & Yogurt & \multicolumn{3}{c}{ Temperature ${ }^{\mathbf{0}} \mathbf{C}$} \\
\cline { 2 - 5 } & parameter & $\mathbf{2 5}$ & $\mathbf{3 5}$ & $\mathbf{4 5}$ \\
\cline { 3 - 5 } Langmuir & $\mathrm{Q}_{\mathrm{m}}(\mathrm{mg} / \mathrm{g})$ & 6.459 & 23.98 & 40.00 \\
& $\mathrm{~K}_{\mathrm{L}}(\mathrm{L} / \mathrm{g})$ & 0.462 & 0.713 & 0.150 \\
& $\mathrm{R}^{2}$ & 0.9062 & 0.9395 & 0.9246 \\
\multirow{3}{*}{ Freundlich } & $\mathrm{K}_{\mathrm{F}}(\mathrm{L} / \mathrm{g})$ & 0.275 & 0.333 & 0.683 \\
& $\mathrm{n}$ & 0.5 & 1.09 & 0.735 \\
& $\mathrm{R}^{2}$ & 0.978 & 0.993 & 0.896 \\
\hline
\end{tabular}

The Langmuir isotherm assumes that the adsorption occurs on a single layer of the adsorbent on identical limited sites (13). Using Langmuir equation 4:

$$
\frac{1}{\mathbf{q}_{\mathrm{e}}}=\left(\frac{1}{\mathbf{K}_{\mathrm{L}} \mathbf{Q}_{\mathrm{m}}}\right) \frac{1}{\mathbf{C}_{\mathrm{e}}}+\frac{1}{\mathbf{Q}_{\mathrm{m}}}
$$

Where: $\mathrm{K}_{\mathrm{L}}=$ Langmuir equilibrium constant for adsorption $(\mathrm{L} / \mathrm{mg}), \mathrm{Q}_{\mathrm{m}}=$ maximum adsorption capacity $(\mathrm{mg} / \mathrm{g}), \mathrm{q}_{\mathrm{e}}=$ amount adsorbate equilibrium $(\mathrm{mg} / \mathrm{g}), \mathrm{C}_{\mathrm{e}}=$ equilibrium concentration $(\mathrm{mg} / \mathrm{L})$.

By plotting $1 / \mathrm{q}_{\mathrm{e}}$ verses $1 / \mathrm{C}_{\mathrm{e}}$ Fig. 6 , it is clear that there is an agreement between the experimental data at high value of correlation factor $\mathrm{R}^{2}$, while the values of $\mathrm{Q}_{m}$ are higher than expected which indicates the incompatibility with the Langmuir model.

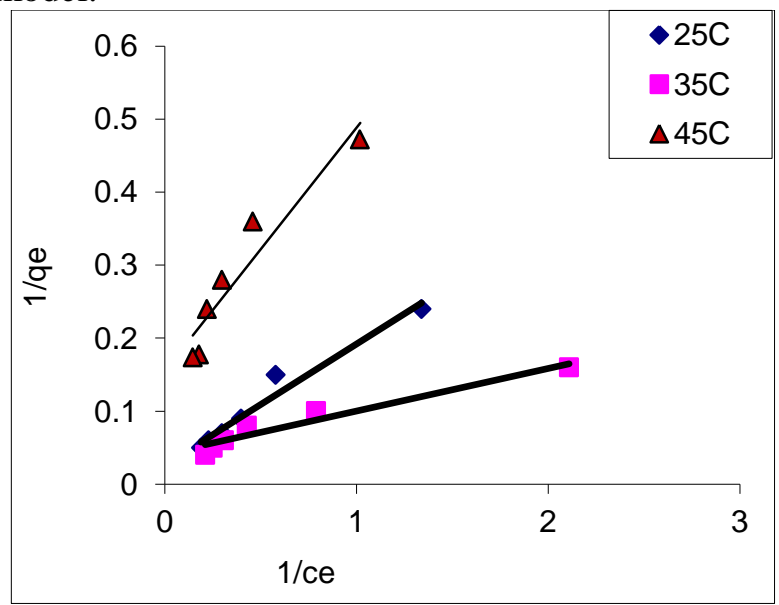

Figure 6. Relationship between $1 / q_{e}$ and $1 / C_{e}$ in Langmuir model

Freundlich equilibrium adsorption isotherm model assumes that the adsorption occur by one layer of heterogeneous surface and gives a linear Freundlich equation (14).

$\log \mathrm{q}_{\mathrm{e}}=\log \mathrm{K}_{\mathrm{F}}+1 / \mathrm{n} \log \mathrm{C}_{\mathrm{e}}$
$\mathrm{K}_{\mathrm{F}}$ and $\mathrm{n}$ are the isotherm constants of the Freundlich equation. Plotting of $\log \mathrm{q}_{\mathrm{e}}$ versus $\log \mathrm{C}_{\mathrm{e}}$ at different temperature, the linear plot indicates that adsorption follows Freundlich isotherm as shown in Fig. 7.

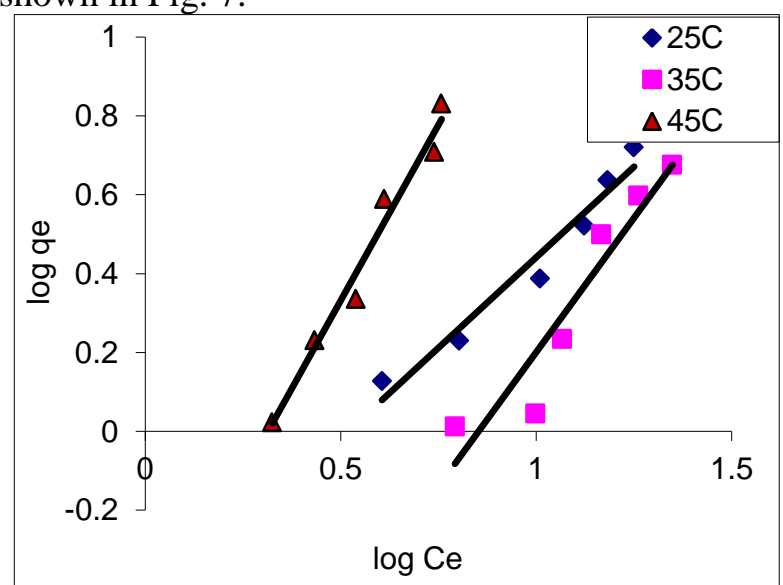

Figure 7. Relationship between $\log q_{e}$ and $\log C_{e}$ in Freundlich model

There are two different types of adsorption, chemical and physical. Value of $\mathrm{n}$ in Freundlich equation can be used to determine the type of adsorption. If $n$ value is less than one, this means the adsorption is chemical, while if value of $n$ is more than one, this indicates that the adsorption process is physical (15). As shown in table 1, the adsorption process is physical at temperature of 35 ${ }^{\circ} \mathrm{C}$, while the adsorption at both 25 and $45{ }^{\circ} \mathrm{C}$ is chemical process.

\section{Kinetics of Adsorption}

Studying the kinetics is very important for understanding the adsorption reaction. This is done by suggesting kinetic models and studying their applicability to experimental adsorption data. Parameters of first and second order reaction are listed in table 2. 
Table 2. Kinetic parameters for the adsorption

\begin{tabular}{ccccc}
\hline Kinetic Model & Parameter & \multicolumn{3}{c}{ Temperature ${ }^{\mathbf{0}} \mathbf{C}$} \\
\cline { 3 - 5 } & & $\mathbf{2 5}$ & $\mathbf{3 5}$ & $\mathbf{4 5}$ \\
\hline \multirow{2}{*}{ First- Order } & $\mathrm{q}_{\mathrm{e}} \exp (\mathrm{mg} / \mathrm{g})$ & 0.533 & 0.316 & 0.372 \\
Kinetic Model & $\mathrm{k}_{1} \times 10^{2}\left(\mathrm{~min}^{-1}\right)$ & 0.029 & 0.048 & 0.023 \\
& $\mathrm{q}_{\mathrm{e}}$ calc. $(\mathrm{mg} / \mathrm{g})^{2}$ & 3.418 & 3.998 & 3.182 \\
& $\mathrm{R}^{2}$ & 0.9748 & 0.9709 & 0.9246 \\
Second- Order & $\mathrm{k}_{2} \times 10^{2} \cdot\left(\mathrm{g} \mathrm{mg}^{-1} \mathrm{~min}^{-1}\right)$ & 0.126 & 0.015 & 0.166 \\
Kinetic Model & $\mathrm{q}_{\mathrm{e}}$ calc. $(\mathrm{mg} / \mathrm{g})^{\mathrm{N}^{2}}$ & 3.484 & 4.80 & 3.226 \\
& $\mathrm{R}^{2}$ & 0.9983 & 0.9889 & 0.9983 \\
\hline
\end{tabular}

Equation 6 is a model of the pseudo first order (16):

$$
\log \left(\mathrm{q}_{\mathrm{e}}-\mathrm{q}_{\mathrm{t}}\right)=\log \mathrm{q}_{\mathrm{e}}-\frac{\mathrm{k}_{1}}{2.303} \mathrm{t}
$$

Where, $q_{e}$ and $q_{t}$ represent the concentration of the adsorbed metal ion $\left(\mathrm{mg} \mathrm{g}^{-1}\right)$ at time $t$ and at solid phase equilibrium respectively, and $k_{1}$ is the first order constant of the adsorption $\left(\mathrm{min}^{-1}\right)$. Plotting of $\log \left(\mathrm{q}_{\mathrm{e}}-\mathrm{q}_{\mathrm{t}}\right)$ vs. $t$ give a straight line and the constant of the rate can be calculated from the slope of the straight line Fig. 8.

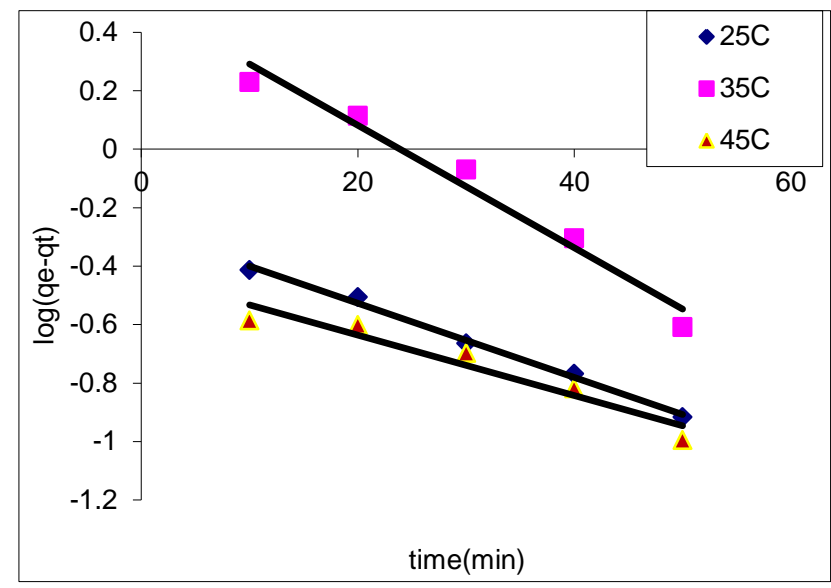

Figure 8. First order plot of adsorption of $\mathrm{Cr}^{6+}$ on Drying Yogurt.

Equation 7 represents the pseudo second order reaction of $\mathrm{Cr}^{6+}$ on drying yogurt (16).

$$
\mathrm{t} / \mathrm{q}_{\mathrm{t}}=\frac{1}{\mathrm{~K}_{2} \mathrm{q}_{\mathrm{e}}^{2}}+\frac{1}{\mathrm{q}_{\mathrm{e}}}
$$

Where $k_{2}$ constant rate of pseudo-second order adsorption $\left(\mathrm{g} \mathrm{mg}^{-1} \cdot \mathrm{min}^{-1}\right)$, plotting of $\mathrm{t} / \mathrm{q}_{\mathrm{t}} \mathrm{vs}$ time should be straight-line as shown in Fig. 9.

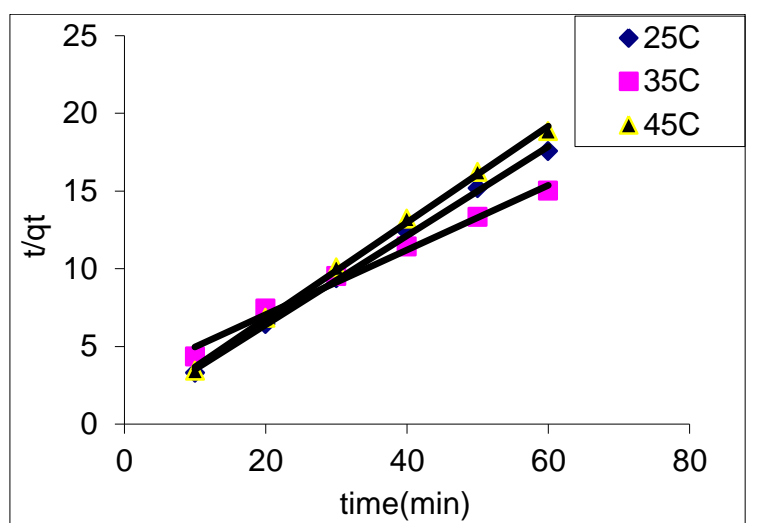

Figure 9. Second order plot of adsorption of $\mathrm{Cr}^{6+}$ onto Drying Yogurt.

Linearity of plotting of two kinetic models shows the reaction follow the second order mechanism more than the first order mechanism.

\section{Thermodynamic Parameters of Adsorption}

Some thermodynamic parameters such as changes in enthalpy $\left(\Delta \mathrm{H}^{\circ}\right)$, entropy $\left(\Delta \mathrm{S}^{\circ}\right)$ and free energy $\left(\Delta G^{\circ}\right)$ were calculated in this study from the following equations (17).

$$
\begin{gathered}
\mathrm{K}_{\mathrm{eq}}=\mathrm{C}_{\text {solid }} / \mathrm{C}_{\text {liquid }} \ldots \ldots \ldots \ldots \ldots \ldots \\
\ln \mathrm{K}_{\mathrm{eq}}=\frac{\Delta s^{\circ}}{\mathrm{R}}-\frac{\Delta \mathrm{H}^{\circ}}{\mathrm{RT}} \ldots \ldots \ldots \ldots \ldots \ldots \\
\Delta \mathrm{G}^{\circ}=-\mathrm{RT} \ln \mathrm{K}_{\mathrm{eq}} \ldots \ldots \ldots \ldots \ldots \ldots
\end{gathered}
$$

Where $\mathrm{K}_{\mathrm{eq}}$ equilibrium constant, $\mathrm{C}_{\text {solid }}, \mathrm{C}_{\text {liquid }}$ are the equilibrium adsorbate concentrations at solid and liquid phase $(\mathrm{mg} / \mathrm{L}), \mathrm{T}$ is the absolute temperature of the reaction $\left({ }^{\circ} \mathrm{K}\right)$ and $\mathrm{R}$ is the gas constant $\left(8.314 \mathrm{Jmol}^{-1} \mathrm{~K}^{-1}\right) . \Delta \mathrm{H}^{\circ}$ and $\Delta \mathrm{S}^{\circ}$ are determined by using Vant Hoff equation (eq. 9) and calculated intercept and slop of plotting $\mathrm{K}$ 。 vs $1 / \mathrm{T}$ Fig. 10. 


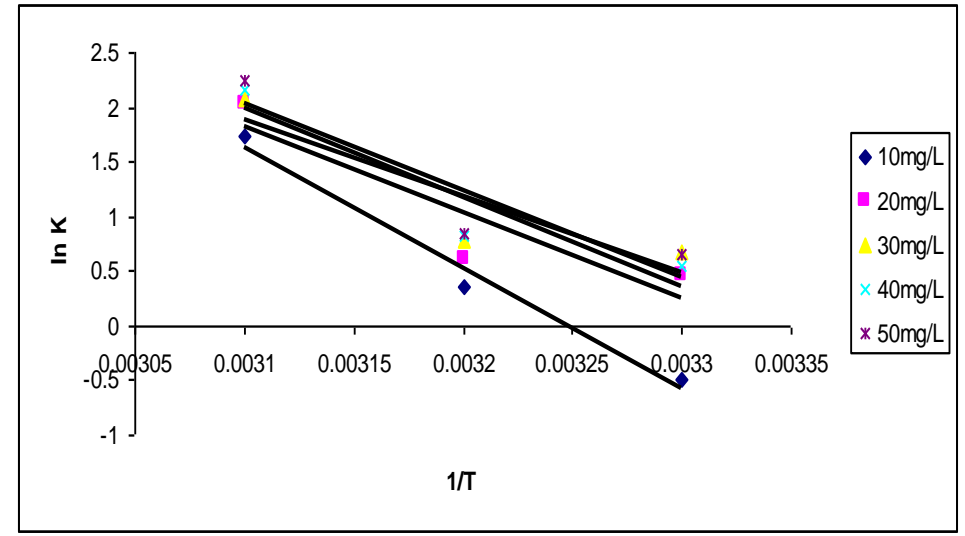

Figure 10. Vant Hoff Equation plot at different concentration.

Calculated thermodynamic parameters are shown in table 3.

Table 3. Calculated values of thermodynamic parameters

\begin{tabular}{ccccccc}
\hline $\mathbf{C r}^{-\mathbf{6}}$ & $\Delta \mathbf{H}^{\circ}$ & $\Delta \mathbf{S}^{\circ}$ & \multicolumn{4}{c}{$\Delta \mathbf{G}^{\circ} \mathbf{K J m o l}^{-\mathbf{1}}$} \\
\cline { 5 - 7 } $\mathbf{C o n} . \mathbf{~ m g} / \mathbf{L}$ & $\mathbf{K J m o l}^{-1}$ & $\mathbf{J m o l}^{-1} \mathbf{k}^{-1}$ & $\mathbf{2 5}^{\circ} \mathbf{C}$ & $\mathbf{3 5}^{\circ} \mathbf{C}$ & $\mathbf{4 5}^{\circ} \mathbf{C}$ & $\mathbf{R}^{\mathbf{2}}$ \\
\hline 10 & -1.140 & -43.55 & -2.096 & -2.302 & -2.945 & -0.8793 \\
20 & -10.018 & -40.175 & -2.088 & -2.565 & -2.865 & -0.9671 \\
30 & -9.519 & -38.629 & -2.125 & -2.565 & -2.873 & -0.9754 \\
40 & -9.020 & -36.683 & -2.118 & -2.289 & -2.834 & -0.897 \\
50 & -8.76 & -33.98 & -1.987 & -2.023 & -2.451 & -0.948 \\
\hline
\end{tabular}

In this study, the calculated values of $\Delta \mathrm{H}^{\circ}$ are negative, and this means the adsorption was exothermic process, while the calculated values of $\left(\Delta \mathrm{S}^{\circ}\right)$ were negative as well, which means that the molecules are more ordered in liquid-solid interphase compared to liquid phase. The free energy values $\left(\Delta G^{\circ}\right)$ of adsorption process were measured and show positive values, which indicated the non-spontaneous nature of the adsorption process (18).

\section{Acknowledgments :}

The authors would like to thank AlMustansiriyah University Baghdad-Iraq for its support in the present work.

\section{Conclusion}

Drying yogurt can be used as an effective absorbent material for hexavalent Chromium ion and possibly other metal ions as well. Drying yogurt can remove more than $80 \%$ of hexavalent chromium from waste water. Drying yogurt could be used in waste water purification.

\section{Conflicts of Interest: None.}

\section{Reference:}

1. Monisha J, Tenzin T, Naresh A, Blessy B, Krishnamurthy N. Toxicity, mechanism and health effects of some heavy metals. J. Interdiscip Toxicol. 2014 Jun; 7(2): 60-72.
2. Chunxiang L, Sha Q, Wei L, Yifan L, Danhui L, Xiaojuan L, Minghua L, J. BioResources. 2014; 4(9):6998-7017.

3. Ali J S. Adsorption of Hexavalent Chromium Ion from Aqueous Solution by Sodium Alginate and Carboxymethyl Cellulose Beads: Kinetics and Isotherm Studies. J. JNUS. 2015; 18 (4): 40-48.

4. Calder LM. Chromium contamination of groundwater, in chromium in the natural and human environments. Wiley Series in Adv. in Env. Sci. and Tech., 1988: 202: 15- 229. New York: John Wiley and Sons.

5. Mishra S, Bharagava RN. J Environ Sci Health C Environ Carcinog Ecotoxicol Rev. 2016; 34,1, 1-32.

6. Lokendra $\mathrm{T}$ and Mukesh P., Adsorption of heavy metal $\left(\mathrm{Cu}^{2+}, \mathrm{Ni}^{2+}\right.$ and $\left.\mathrm{Zn}^{2+}\right)$ from synthetic waste water by tea waste adsorbent Int J. of Chem. and Phy. Sc., 2013; 2(6): 6-19.

7. Derbe T, Dargo H, and Batu W. Cactus potential in heavy metal $(\mathrm{Pb}$ and $\mathrm{Cd})$ removal in water sample collected from rural area around Adigrat town, Chemistry and Materials Research, 2015; 7(3): 84-92.

8. Sharma Y C, Weng CH. Removal of chromium (VI) from water and wastewater by using riverbed sand: Kinetic and equilibrium studies, J. Hazard. Mat., 2007; 142:449-454.

9. Dhal B, Thatoi HN, Das NN, Pandey BD. Chemical and microbial remediation of hexavalent chromium from contaminated soil and mining/metallurgical solid waste: A review. J. Hazard. Mater. 2013; (250251): 272-291.

10. Ansari R. Application of polyaniline and its composites for Adsorption/ Recovery of chromium (VI) from aqueous solutions. Acta Chim. Solv., 2006; 53:88-94. 
11. Memon JR, Memon SQ, Bhanger MI, El-Turki A, Hallam KR, Allen GC. Banana peel: A green and economical sorbent for the selective removal of Cr(VI) from industrial wastewater, J. Colloids Surf B Biointerfaces, 2009; 70:232-237.

12. Al-Qahtani KM. Water purification using different waste fruit cortexes for the removal of heavy metals, J. Taibah Univ Sci, 2016; 10(5): 700-708.

13. Reyhaneh S, Reza F, Zahra S, Narges E. Monolayer and multilayer adsorption isotherm models for sorption from aqueous media. Korean J Chem Eng., 2015 May; 32(5):787-799.

14. Hamzaoui M, Bestani B, Benderdouche N. The use of linear and nonlinear methods for adsorption isotherm optimization of basic green 4-dye onto sawdust-based activated carbon, J. Mater. Environ. Sci., 2018; 9(4): 1110-1118.
15. El Nemr A, Pomegranate husk as an adsorbent in the removal of toxic chromium from wastewater, J. Chem. Ecol., 2007; 23(5): 409-425.

16. Zadaviciute S, Baltakys, K, Eisinas A, Bankauskaite A. Simultaneous adsorption at $25{ }^{\circ} \mathrm{C}$ and the peculiarities of gyrolite substituted with heavy metals. J. Therm. Anal. Calorim. 2017; 127:335-343.

17. Arivoli S, Hema M, Karuppaiah M, Saravanan S. Adsorption of chromium ion by acid activated low cost carbon-Kinetic, Mechanistic, Thermodynamic and Equilibrium Studies, J Chem. 2008; 5(4): 820831.

18. Tounsadi H, Khalidi A, Abdennour M, Barka N. Biosorption potential of Diplotaxis harra and Glebionis coronaria L. biomasses for the removal of $\mathrm{Cd}(\mathrm{II})$ and $\mathrm{Co}(\mathrm{II})$ from aqueous solutions, J Environ Chem Eng, 2015; 3(3): 822-830.

\section{إزالة الكروم السداسي من المحاليل المائية بإستخدام اللبن الزبادي المجفف، دراسة الائوثيرم والحركية

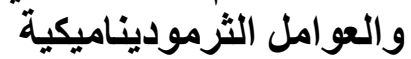

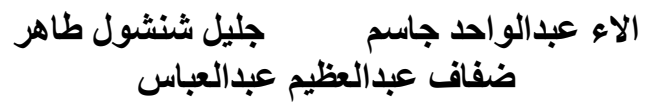

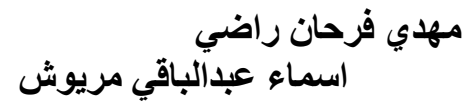

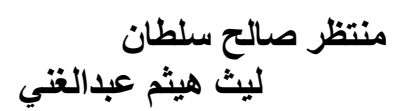

قسم الكيمياء، كلية العلوم، الجامعة المستنصرية، بغداد، العر اق.

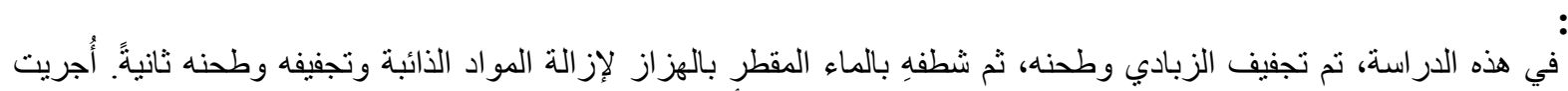

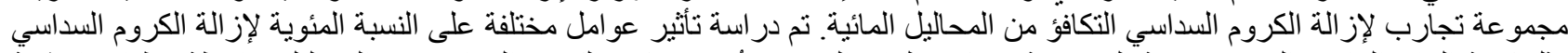

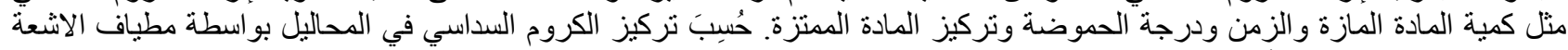

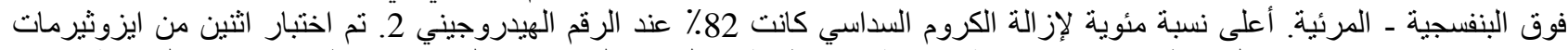

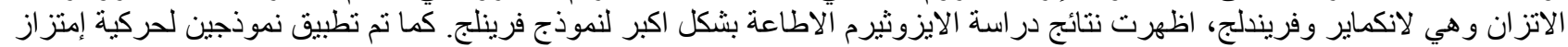

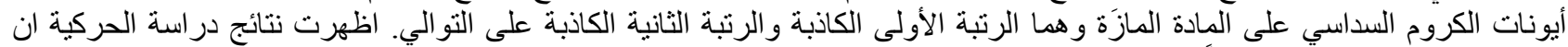

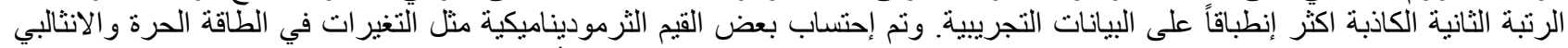

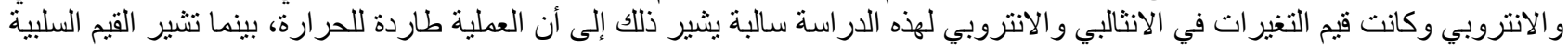
اللتغير في ألطاقة الحرة إن العملية تلقائية.

$$
\text { الكلمات المفتاحية: الامتزاز ، ايزوثيرمات الامتزاز، حركية الامتزاز، الكروم السداسي، الزبادي }
$$

